\title{
An unusual cause of biliary colic
}

\author{
Gokulakrishnan Balasubramanian 1,2
}

1 Madras Medical College,

Chennai, Tamil Nadu, India ${ }^{2}$ Department of Internal

Medicine, Rosalind Franklin University of Medicine and Science, Des Plaines, Illinois, USA

\section{Correspondence to}

Dr Gokulakrishnan

Balasubramanian,

drbgokul@gmail.com

Accepted 9 April 2014

\section{(a) CrossMark}

To cite:

Balasubramanian G. BMJ

Case Rep Published online:

[please include Day Month

Year] doi:10.1136/bcr-2014204200

\section{DESCRIPTION}

A 40-year-old woman presented with postprandial abdominal pain in the epigastric region for 4 days. In the past 6 months, she had intermittent abdominal pain in spite of 6 weeks of proton pump therapy and weight loss of $10 \mathrm{~kg}$. She denied any history of melena, haematochezia, fever, jaundice, vomiting or diarrhoea. Her physical examination was unremarkable. Laboratory studies revealed mild leucocytosis $\left(11540 / \mathrm{mm}^{3}\right)$, normal heamoglobin level, normal pancreatic enzymes, mild transaminitis (aspartate transaminase: $82 \mathrm{IU}$ (normal range: $30-40 \mathrm{IU} / \mathrm{dL}$ ) and alanine transaminase: $94 \mathrm{IU}$ (normal range: 30-40 IU/dL)) and normal iron studies. She underwent upper endoscopy in view of her dyspeptic symptoms and weight loss. Upper endoscopy revealed ascaris lumbricoides (B) emerging from the major duodenal papilla (A) (figure 1). Following endoscopic extraction of the worm, the patient had clinical recovery with oral albendazole. During follow-up, her liver enzymes and biliary imaging were normal.

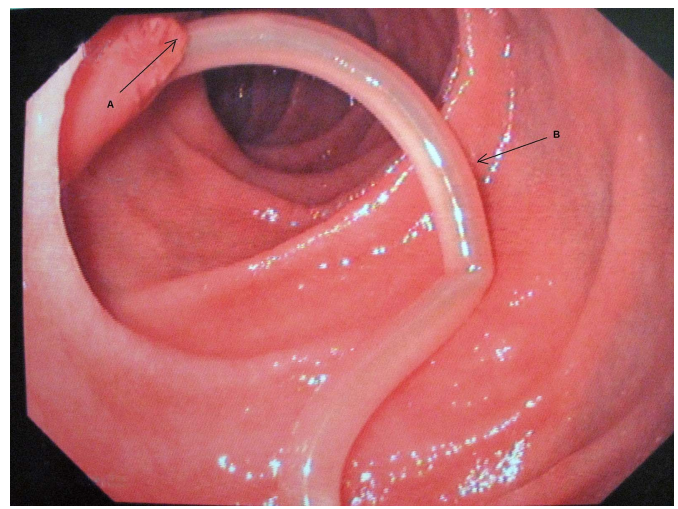

Figure 1 Biliary ascariasis-ascaris lumbricoides (B) emerging out of the duodenal papilla (A).

\section{Learning points}

- Ascaris lumbricoides is one of the most common intestinal helminthic infestations affecting nearly one billion people of all ages worldwide, of which $73 \%$ live in Asia. ${ }^{1}$

- In endemic areas, most of them present with non-specific symptoms. Migration of the worm into the biliary tree can present with hepatobiliary and pancreatic symptoms.

- Diagnosis is usually by stool microscopy. Ultrasound, CT and MRI can also help visualise the worms when the infestation is heavy. Endoscopic removal of the worm from the biliary tree results in immediate complete resolution of symptoms. ${ }^{2}$ This has to be followed by antihelminthic treatment with agents such as albendazole (400 mg once a day) or mebendazole (500 $\mathrm{mg}$ once a day or $100 \mathrm{mg}$ twice a day for 3 days) for complete resolution of the infestation. ${ }^{3}$ Pyrantel pamoate is the agent of choice for pregnant women.

Competing interests None.

Patient consent Obtained.

Provenance and peer review Not commissioned; externally peer reviewed.

\section{REFERENCES}

1 Tietze PE, Tietze PH. The roundworm, ascaris lumbricoides. Primary Care 1991;18:25-41.

2 Astudillo JA, Sporn E, Serrano B, et al. Ascariasis in the hepatobiliary system: laparoscopic management. J Am Coll Surg 2008;207:527-32.

3 Bethony J, Brooker S, Albonico $M$, et al. Soil-transmitted helminth infections: ascariasis, trichuriasis, and hookworm. Lancet 2006:367:1521-32.

Copyright 2014 BMJ Publishing Group. All rights reserved. For permission to reuse any of this content visit

http://group.bmj.com/group/rights-licensing/permissions.

BMJ Case Report Fellows may re-use this article for personal use and teaching without any further permission.

Become a Fellow of BMJ Case Reports today and you can:

- Submit as many cases as you like

- Enjoy fast sympathetic peer review and rapid publication of accepted articles

- Access all the published articles

- Re-use any of the published material for personal use and teaching without further permission

For information on Institutional Fellowships contact consortiasales@bmjgroup.com

Visit casereports.bmj.com for more articles like this and to become a Fellow 